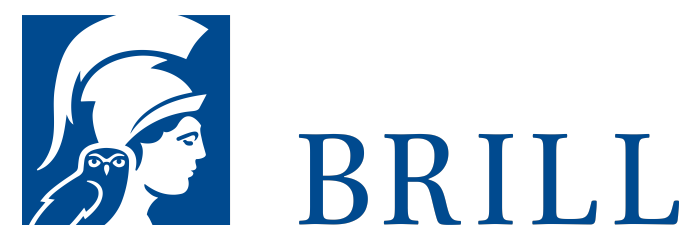

\title{
Deutsche Feindaufklärung vor dem Ersten Weltkrieg
}

Informationen und Einschätzungen des deutschen Generalstabs zu den Armeen Frankreichs und Russlands 1904 bis 1914

Author: Lukas Grawe

Militärische Geheimdienstarbeit ist kein Phänomen der Moderne. Allerdings lösten seit der Mitte des 19. Jahrhunderts die rasanten Entwicklungen der Waffen- und Kommunikationstechnik, im Eisenbahnbau und in der Logistik einen gesteigerten Informationsbedarf aus, der zu einem tiefgreifenden Wandel im militärischen Geheimdienstwesen führte.

Besonders in der Zeit von 1904 bis 1914 gewann die »Feindaufklärung « für den deutschen Generalstab an Bedeutung. Die militärische Führung des Deutschen Reichs war auf genaue Informationen über potenzielle Gegner angewiesen, um auf die politischen und militärischen Entwicklungen, vor allem in Frankreich und Russland, reagieren und die eigene militärische Planung und Rüstung darauf abstimmen zu können. Der Autor befasst sich mit der Bedeutung der Feindaufklärung sowie den Informationen und Einschätzungen des deutschen Generalstabs zu feindlichen Armeen.

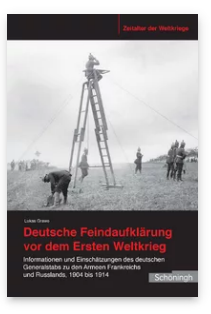

Pages: XII +532 Seiten, $10 \mathrm{~s} / \mathrm{w}$ Abb., 2 s/w Tab. Language: German

Subjects: Early Modern History, History

Publisher: Brill| Schöningh

Series:

Zeitalter der

Weltkriege,

Volume: 16

Hardback

Publication date: o8 Sep 2017

ISBN: 978-3506-78789-7

List price

USD $\$ 75.00$ 
Lukas Grawe hat Geschichte und Germanistik an der Universität Münster studiert und ist seit 2016 wissenschaftlicher Mitarbeiter am SOCIUM Forschungszentrum der Universität Bremen.

For more information see brill.com

\begin{abstract}
Order information: Order online at brill.com +44330 333 0049 | customerservices@brill.com Submission information: brill.com/authors
\end{abstract}

Titles published by Brill | Fink, Brill | mentis or Brill | Schöningh: +49(o)71 5413279216 | brill@brocom.de 